UDK 341.64

\title{
TRAVAUX PREPARATOIRES: APPLICATION BY THE INTERNATIONAL COURT OF JUSTICE IN INTERPRETATION OF INTERNATIONAL LAW
}

\section{TRAVAUX PREPARATOIRES: ЗАСТОСУВАННЯ МІЖНАРОДНИМ СУДОМ ООН У ІНТЕРПРЕТАЦІЇ МІЖНАРОДНОГО ПРАВА}

\section{TRAVAUX PREPARATOIRES: ПРИМЕНЕНИЕ МЕЖДУНАРОДНЫМ СУДОМ ООН В ИНТЕРПРЕТАЦИИ МЕЖДУНАРОДНОГО ПРАВА}

\author{
Karvatska S.
}

$\mathrm{Ph} \mathrm{D}$ in Law, Doctoral Candidate at the Institute of International Relations of Taras Shevchenko National University of Kyiv, Associate Professor at Yuri Fedkovych Chernivtsi National University. E-mail: svitlana.karvatska288822@gmail.com

\section{Карвацька С. Б.}

Кандидат юридичних наук, докторант Інституту міжнародних відносин Київського національного університету імені Тараса Шевченка, доцент Чернівецького національного університету ім. Ю. Федьковича. Електронна пошта: svitlana.karvatska288822@gmail.com

Карвацкая С. Б.

Кандидат юридических наук, докторант Института международных отношений Киевского национального университета имени Тараса Шевченко, доцент Черновицкого национального университета им. Ю. Федьковича. Електронна пошта: svitlana.karvatska288822@gmail.com

Abstract. The article is devoted to the analysis of the nature, essence and mechanism of the application of travaux preparatoires by the International Court of Justice (ICJ) in the process of interpreting the international law. It is proved that the interpretational practice of the ICJ shows the extension of the doctrinal approaches of the traditional perception of travaux preparatoires as an auxiliary tool.

It has been established that the ICJ uses travaux preparatoires 1 to identify the intent of the legislator; 2 to provide advisory opinions; 3 to clarify the intentions of the parties to the treaty; 4) to determine the jurisdiction of the ICJ; 5) to identify the true intentions of the parties to the dispute; 6) to decide questions regarding the text, context, purpose and object of the treaty as a general rule of interpretation, fixed in Art. 31 of the Vienna Convention on the Law of Treaties, 1969.

Key words: travaux preparatoires, International Court of Justice (ICJ), Interpretation, Vienna Convention on the Law of Treaties, 1969.

Анотація. Статтю присвячено аналізу природи, сутності та механізму застосування Міжнародним Судом travaux preparatoires y процесі інтерпретаиіi міжнародного права. Доведено, що інтерпретащійна практика МС ООН свідчить про розширення доктринальних підходів традииійного сприйняття travaux preparatoires як допоміжного інструменту.

Встановлено, що МС ООН використовуе travaux preparatoires 1) для можливості виявлення наміру законодавия; 2 для надання консультативних висновків 3) для уточнення намірів сторін договору; 4) для встановленння юрисдикції $M C$; 2) для з'ясування істинних намірів сторін спору; 5) для вирішення спору щодо тексту, контексту, мети $і$ об'єкта договору згідно із загальним правилом інтерпретачії, зафіксованого у ст. 31 Віденської конвениії про право договорів 1969 р. 
Ключові слова: travaux preparatoires, Міжнародний Суд ООН, інтерпретачія, Віденська конвенщія про право договорів 1969 p.

Аннотация. Статья посвящена анализу природь, сущности и механизма применения Международным Судом travaux preparatoires в прочессе интерпретаиии международного права. Доказано, что интерпретаџионная практика МС ООН свидетельствует о расширении доктринальных подходов традичионного восприятия travaux preparatoires как вспомогательного инструмента.

Установлено, что МС ООН использует travaux preparatoires 1) для возможности уяснения намерения законодателя; 2) для предоставления консультативных заключений 3) для уточнения намерений сторон договора; 4) для определения юрисдикиии МC; 2) для уяснения истинных намерений сторон спора; 5) для разрешения спора относительно текста, контекста, цели и объекта договора по общему правилу интерпретации, закрепленного в $\mathrm{cm} .31$ Венской конвенции о праве договоров 1969 .

Ключевые слова: travaux preparatoires, Международный Суд $O O H$, интерпретачия, Венская конвенчия о праве договоров 1969.

The current problem. The application of travaux preparatoires is practiced in various international courts both at the global and regional levels. The most authoritative is their use as supplementary materials by the International Court of Justice (ICJ), because in this case they become the source of international law. Academics note the skeptic attitude of the ICJ to travaux, but at the same time they recognize its repeated use in the proceedings [Ris, 1991]. The travaux preparatoires ("preparatory work"), borrowed from French, denotes all documents (memorandums, conferences protocols and draft agreements used during negotiations for the interpretation of the treaty [26], which may include various materials: preliminary draft agreements, correspondence of the negotiating states, records of their comments to the plenary committee, the reports of the committees, the reports of the speakers, and sometimes public statements by theex officio of negotiating states, the state figures, and the materials recorded as "authentic interpretation".

Analysis of the latest publication. The problem of travaux preparatoires is mainly in the focus of Western academics. Among the scholars who pay attention to the problem of travaux preparatoires applications within international courts, it is worth mentioning such as Marco Benatar, Marc J. Bossuyt, Matthew C.R. Jef, Djeffal Christian, Sharon Detrick, M. McDougal, Gerald Fitzmaurice, Erik Frank, Hersh Lauterpacht, Mark van Hook, Francisco Lertora Pinto, Jonathan Pratter, Dietrich Rauschning, Lars A. Rehof, Martin Ris, Detrick, Sharon, Detlev F. Vagts, William A. Schabas, Paul Weis, Ralf Günter Wetzel, Peter Quayle. Among Ukrainian researchers it is worth highlighting Y. Movchan. However, there are no general, systematic and comprehensive studies of the specifics of travaux preparatoires application.

The aim of the article. The aim of the article is to determine the nature, essence and mechanism of the application of travaux preparatoires by the ICJ in the process of interpreting international law.

Important research results. In contrast to the American tradition, in Europe, individual scholars, in particular, Mark van Hook, include to travaux preparatoires only the legislative materials that make it possible to identify the intentions of the legislator, contain information that is important for understanding the meaning of the law [Van Khuk, 2012: 192]. Their classification depends on what kind of information they contain: 1) the genesis of the bill (evolution of the bill in the process of consideration in parliament); 2) explanatory notes accompanying various texts, critique of draft laws, answers to questions, etc. 
It is commonly accepted that documents used as travaux preparatoires are usually official, and exist, firstly, in writing, and secondly, available and known to all negotiating states. They relate to the fixing of the negotiations, development and discussion during the conclusion of the treaty, statements, reservations, etc. Moreover, this process is quite lengthy; it can take place over several years, "with careful preparation and discussion" [Van Khuk, 2012: 192-193]. Documents are considered and even taken into account not only during the conclusion of the treaty, but also for the interpretation of them, and therefore the importance of such materials cannot be underestimated.

However, scholars are confronted with the incredible complexity in their search, since most of these documents are not published, or they are published on the sites of international organizations, they are often not available to the general public, or confidential (most treaties of the Council of Europe), and when they are published in collections, it is often difficult to identify the right document among thousands of preparatory materials. The difficulty lies in the fact that, according to Detlev F. Vagts, "there is no way to know it for sure, since there is no international registry where all treaties are filed to create a complete inventory" [25], and needless to say about the preparatory materials.

Well-known collections are the travaux preparatoires for the Convention for the Protection of Human Rights and Fundamental Freedoms (1951) [4], the Refugee Convention (1951) [Weis, 1995] the International Covenant on Civil and Political Rights (1966) [Bossuyt, 1987], the International Covenant on Economic, Social, and Cultural Rights (1966) [Craven, 1995], Vienna Convention on the Law of Treaties (1969) (VCLT) [Detrick, 1992], the United Nations Convention on the Elimination of all Forms of Discrimination Against Women (1979) [Craven, 1995], the United Nations Convention on the Rights of the Child (1989) [Günter, Dietrich, 1978]. However, most of the materials are contained on the websites of organizations, or not available for study. Martin Ris proposed a series of amendments to Art. 32 of the VCLT, 1969 [Ris, 1991: 133]:

First, the author emphasizes that the ICJ is charged with determining the certified categories of preparatory work that make up the official travaux préparatoires. But at the same time, Martin Ris notes that the amount of travaux préparatoires should be limited so that the habitual appeal is not overly burdensome for judicial practice. It is logical to conclude that at the same time the amount of travaux préparatoires materials should allow the parties to communicate their opinions on issues related to the interpretation of the treaty. Secondly, it is very important and appropriate to suggest the creation and retention of official travaux preparatoires documents by the UN Depositary. The ICJ shall appoint a depositary of travaux preparatoires.

Of course, the main source of interpretation of treaties is the VCLT, the three articles of which contain general rules of interpretation for all founding treaties of international organizations, however, according to M. McDougal, "they are completely eclectic, embracing all interpretive approaches" [McDougal, 1967]. Detlev F. Vagts states that most observers consider them to be the "normal simulation" hierarchy at the top. The original intention gets a secondary role when it turns out that the parties determined a particular meaning. In this case, the use of travaux preparatoires is justified [25]. However, problems of interpretation can, of course, be resolved within the framework of the VCLT, but social and technological changes and consideration of the concepts of "state policy", "protection of morality", "internal jurisdiction", "territorial sea", "continental shelf" and others violate issues of improvement of Art. 31 and 32 regarding travaux preparatoires, in particular. The interpretation of the conventions of the United Nations on the basis of travaux preparatoiress not very extensive up to two dozen cases, but its analysis leads to considerations of revision in the context of expanding the doctrinal approaches of traditional perception of travaux preparatoires precisely as an auxiliary instrument.

Scholars have not reached a common ground on the main approaches (schools) when using travaux preparatoires in the interpretation of international treaties by the ICJ. In this 
regard, Christian Djeffal poses the question: "Is it compatible with the VCLT to apply principles, presumptions, or schools of interpretation? And are these tools compatible with each other? Which rule should outweigh? [Djeffal, 2016: 35]. The scientist characterizes the discourse around this issue as "perfect polyphony: many voices sings different tunes that are harmonious to themselves, but not to each other," and states that the authors generally suggest an approach without discussing alternatives or justifying why this approach should be followed. As a conclusion: it is possible to follow the decisions of those who prepared the draft of the conventions, i.e. travaux preparatoires.

To find out the effectiveness of one approach or another, we will analyze the practice of the ICJ in cases where it used travaux preparatoires. We can confidently speak of the benefits of a textual approach to interpretation at the initial stage of the functioning of the ICJ. Much less, the ICJ sought clarification of intentions when it was necessary to follow the behavior of the parties before and after the conclusion of the treaty, to analyze historical aspects, to identify true intentions regarding the goals and objectives of the parties, the jurisdiction etc. But over the time, the ICJ gives more attention to the school of intentions than to other approaches, especially in the context of the use of travaux preparatoires, which can shed light on what the parties have foreseen when entering into the treaty. Increasingly, the importance of authentic means of interpretation led to a reduction in the importance of literary interpretation, which prevailed in the initial mechanical phase.

Yes, it was in order to confirm the intentions of the developers of the Geneva Convention for the Protection of Victims of the War, 1949 [3]. The ICJ used travaux preparatoires to advise on the legal consequences of the construction of the wall by the occupying Israel forces in the occupied Palestinian territory, including in and around East Jerusalem (Legal Consequences of the Construction of a Wall in the Occupied Palestinian Territory dated 9 of July 2004) [6]. Its use was connected with the interpretation of Art. 2 of the aforementioned Convention on the conditions for its application to the Palestinian territory, which, before the 1967-armed conflict, was located on the east of the demarcation of the 1949 ceasefire (the Green Line) and was occupied by Israel during this conflict [6]. Such conditions include the presence of an armed conflict (or a recognized state of war) and the existence of a conflict between the two parties. Under these conditions, Convention IV applies to any territory of one of the parties. The court interpreted the content of this article in the context of the possibility of its application for the protection of civilians in the hands of the occupying state, even if the occupation carried out during the conflict did not encounter the use of weapons [6]. That is, unlike the authors of the Hague Convention, 1907, the developers of the Convention IV sought to protect civilians during the war regardless of the status of the occupied territories in accordance with Art. 47 [6]. The ICJ had confirmed these arguments by referring to the travaux preparatoires of the draft works on Convention IV. In particular, during the 16th Conference of Government Experts convened by the International Committee of the Red Cross for the preparation of new humanitarian agreements, it was stated: "The Convention is equally valid in the case of the occupation of territories in the absence of any state of war. This provision should also be outlined in the Convention ... regarding the protection of civilians during the war" [6]. At the conference, as in the 1937 Commission, unanimous agreement was reached that the Convention should be applied to all cases of armed conflict between states, even in the absence of a declaration of war, and the humanitarian principles that it contains should be respected at any time, even if the Convention is not legally applicable [6]. The analysis of the text allowed the ICJ to ascertain the intention of the drafters of the Convention to foresee cases of occupation without the hostile activities. This understanding was confirmed and endorsed by the states parties to the Convention IV at the conference in 1995. That is, the use of travaux preparatoires confirmed the applicability of the Convention to the occupied Palestinian territory, including East Jerusalem, and the need for the state of Israel to fulfill its obligations [6]. 
At the same time, in terms of clarifying the intentions of the parties, the application of travaux preparatoires by the ICJ would be ineffective, for example, when it concerns the interpretation of Paris Peace Treaties (1947) and Peace Treaties with Bulgaria, Hungary and Romania dated 30 of March 1950 [12]. For example, the use of negotiation materials between the other parties to the treaty would be inappropriate, as they were deliberately avoided by representatives of the delegations of the defeated countries, using them only when it was necessary to sign the treaties drawn up and presented by the winning states. The ICJ's decision would be based de facto on the understanding of the circumstances of the treaties, when they signed "dictated" texts, and not agreed upon in negotiations with the defeated state. They agreed mainly on the positions of the victorious states and their post-war influence in the region [Zhignya, 1981: 223].

The textual approach to the application of travaux preparatoires has been used by the ICJ in the case (Romania v. Ukraine) (2008) [7] concerning the establishment of a single maritime border between the two states in the Black Sea and the delineation of the continental shelf and the exclusive economic areas belonging to them. The ICJ used the three-step approach to maritime delimitation previously developed in a case Maritime Delimitation and Territorial Questions between Qatar and Bahrain, Jurisdiction and Admissibility, in particular: 1) setting a temporary boundary of uniformity; 2) taking into account the factors that impact the correction overall and the correction of the boundary; 3) confirmation that the boundary adjusted this way will not lead to an unfair result by comparing the ratio of coastal lengths with the length of the corresponding maritime areas [10]. It was at the first step, during the setting of the line of uniformity, when it was necessary to select the appropriate bases for the line (on Romanian side - the Sakalin peninsula and Sulin Dam, on Ukrainian side - Tsyganka Island and Cape Tarkhankut), the ICJ referred to travaux preparatoires to substantiate the choice of Sulin Dam as a point. It analyzed the following factors for adjusting delimitation:

1) Possible imbalance between the lengths of coastal strips;

2) The closed nature of the Black Sea and the delineation already made in the region;

3) The presence of the Serpents' Island in the delimitation region; patrols).

4) The behavior of the parties (oil and gas concessions, fishing activities and naval

5) Any possible restriction on the continental shelf or exclusive economic zone by the law of one of the parties;

6) Security considerations of the parties.

The ICJ considered the possibility of characterizing the nature of the Sulin Dam as a "port facility" and "an integral part of the port system," since this definition is not a part of the Convention on the territorial sea and adjacent zone dated 29 of April 1958 [2]. That's why it appealed to travaux preparatoires to Article 8 of the abovementioned Convention that deals with the distinction between dyke and port functions and stated that the concept of a dyke is no longer used by international bodies, but refers mostly to the pier (Article 10) [para 134]. The ICJ used the expert's conclusions, who claimed that the port facilities, the piers in particular, are part of the continental territory at the conference in 1958 [13]. The International Law Commission (ILC) in a report sent to the General Assembly of the United Nations was doubtful about the possibility of application of Art. 8 in case if the pier is too long (protrudes into the sea for several kilometers), however, it has not determined the conditions/limits for which the dyke, pier or object cease to be "an integral part of the port system". Therefore, the ICJ used an individual approach to the deciding that case, since Art. 11 and travaux preparatoires "do not foreclose the possibility of a limited interpretation of the concept of port facilities in order to prevent or simplify the concept of excessive length defined by the ILC" [8], and therefore it can also be used to the case of delimitation of areas that extending territorial waters. That is, in this case, the ICJ departed from usualapproach to understanding the essential terms of the treaty, since the meaning of the treaty, namely the 
Convention on the Territorial Sea and the Adjacent Zone, changes evolutionarily, since the words "dyke, "pier", "port facility" and " an integral part of the port system "are used as general concepts, and not as words of fixed content.

The ICJ emphasized that, since the case had had an international aspect, it relied on the choice of ascending points by both parties, and the choice of ascending points by Ukraine was not contested [8]. Apparently the ICJ applied the classic for travaux preparatoires method of textual interpretation of Art. 8 of the Geneva Convention on Territorial Sea and Contiguous Zone. However, if the subjects of interpretation mostly seek to specify the purpose and object of the treaty, then in this case it was about clarifying the "agreed definitions".

The sufficiently successful was the application ofthe travaux preparatoires for the interpretation of the Treaty between Costa Rica and Nicaragua from 1858 and other documents dealing with maritime delimination (exclusive economic zone and continental shelf) in the Caribbean Sea and the Pacific Ocean (Maritime Delimitation in the Caribbean Sea and the Pacific Ocean (Costa Rica v. Nicaragua) and Land Boundary in the Northern Part of Isla Portilos (Costa Rica v. Nicaragua) 2 February 2018 [9]. In its decision from 2015, the ICJ found "the lack of detailed information", which "left the geographical position of the area somewhat unclear on the configuration of the Isla Portilos coast". This led the ICJ to the consideration of the historical context of the contractual consolidation of the formation of borders and the use of textual interpretation of treaties. The ICJ faced the question of the entry into force of the Treaty from 1858, which consolidated the land borders between the two states. It was confirmed by the Arbitration Decision of the US President Grover Cleveland in 1887, "11 points of dubious interpretation" of which were presented to Nicaragua and Costa Rica in the Treaty of 1886 , which allowed to establish with certainty the "validity of the Treaty of 1858", Art. II of which contained a description of the passage of the border, and in paragraph 3(1) it was recorded that the "borderline between the two states on the Atlantic side" begins at the end of the Punta de Castile at the mouth of the San Juan de Nicaragua, as both of them existed on April 15, 1858" [9].

Historical context was also studied by the ICJ in the context of the Convention on Border Demarcation concluded between Costa Rica and Nicaragua in 1896 and the subsequent process of demarcation by US General Eduard Porter Alexander in 1897, that reported the beginning of the plot and the coordinates of the starting point of the land boundary defined concerning the center of Victoria Square in the ancient San Juan de Nicaragua (Greytown) and other points on the ground" [9]. In general, textual and historical methods have enabled the ICJ to clarify the issue of the territorial sovereignty of the coastal states, which it considered "because of the possible consequences for the delimitation of the seaside in the Caribbean Sea" [9].

A particular example of the reference to the travaux preparatoires is the case of the Maritime Delimitation and Territorial Questions between Qatar and Bahrain (Qatar v. Bahrain) dated 15 of February 1995 [8] on the sovereignty over the Hawar Islands and the sovereign rights over the Dibal and Qit'at Jaradah shoals and delimitation of their marine areas (areas of the seabed, subsoil, surface of the sea). The need to use these materials arose at the stage of establishing the jurisdiction of the ICJ, as both parties insisted, and which was to be determined by the so-called "Bahrain formula". It was proposed by Bahrain, and it was determined to set forth in the correspondence between the King of Saudi Arabia and the emirate of Bahrain and the King of Saudi Arabia, the Emir of Qatar in December 1987; it was specified during the Tripartite Commission meeting in December 1988 (through Saudi Arabia) and Qatar accepted it in 1990, when in the Doha foreign ministers signed the Protocol, which was deemed to be the treaty, under which the "two parties" were obliged to submit the case to the ICJ and that was the essence "Bahrain Formula". However, on 8 of July 1991, only Qatar appealed to the ICJ, which, according to Bahrain, contradicted the theaty, the text of which provided for a joint appeal to the ICJ, and therefore the ICJ had no 
jurisdiction to consider it [8]. The different vision of the text of the theaty was not due to the so-different interpretation of the Arabic text of the expression "al-tarafan", which Qatar translated as "the party", and Bahrain as "parties", but due to the interpretation of these Arab terms in their context, because, in essence, in Arabic this expression implies two units. But whether this is one side or two, courts had to find out by analyzing the content and scope of this phrase. As of 1994, the parties filed Memorials containing the materials necessary for the deciding the dispute. In deciding the issue of jurisdiction, the ICJ examined the content of the documents on "the creation of rights and obligations of the parties" in detail, which, in the Court's opinion, were international treaties [8].

Note that both Qatar and Bahrain believed that the application of Art. 31 of the VCLT is inappropriate, because for them this controversial expression is neither ambiguous nor obscure, nor does it lead to a result which is manifestly absurd or unreasonable [10], and in general, "the Arab-Islamic legal position precludes the application of travaux preparatoires even when interpreting $t$ within the framework of the legislation of different Arab countries» [10]. However, the statements have been denied by the opinions of the members of the ILC of Iraqi and Egyptian origin, Mr. Mustafa Kamil Yasseen and Mr. El-Erian, who "unreservedly support the principle of access to travaux preparatoires in the proper conditions" [10]. In particular, Mr. Yasseen believed that in the case "if the textual interpretation leads to an absurd or unreasonable result, it would be justified to assume that the wording was defective and we must rely on the statements of those who formulated the text. This case is very similar to the error case, and no one denies that the error can be corrected. There is no reason to believe that the analysis of travaux preparatoires and the circumstances, in which the text was composed, will lead to a reasonable value" [10].

The court used a textual and grammatical interpretation, analyzing the forms of words and the logical consequences of the second sentence in paragraph 2 of the Protocol of 1990 and sought to understand why this document, which was intended to facilitate dispute settlement by putting into effect the forms and obligations of the parties to submit it to the ICJ, had limited the possibility of joint action for them. The ICJ also had the task of examining the possible consequences of interpreting Saudi Arabia's mediation conditions, that is, the text was considered in terms of the impact on the parties' right to choose the court, as well as to continue mediation. So, it analyzed the meaning of the treaty and its terms. As a result of the interpretation, in accordance with the usual meaning of the terms in its context, taking into account the object and purpose of the Protocol, it was decided to allow the possibility of a unilateral appeal to the ICJ [8]. This was confirmed by the text of the draft proposed by Oman, which was then taken as the basis of the treaty, where it was clearly stated that the term "al-tarafan" was replaced by the words "any of the parties" [8] and other important edits. This fact, of course, had the advantage of clarifying the circumstances of concluding the treaty, since it was signed during a meeting of the Cooperation Council for the Arab States of the Gulf in Doha in December 1990, convened, first of all, to resolve the conflict between Iraq and Kuwait [8]. Along with this, in order to resolve the conflict between Qatar and Bahrain, Saudi Arabia and Oman have offered draft materials for its settlement, which were used as travaux preparatoires. Thus, the jurisdiction of the ICJ in that case was established.

Conclusions. So, the travaux preparatoires is official, written, available and known to all negotiating states documents, used during negotiations for the interpretation of the treaty: memorandums, conferences protocols and draft agreements, preliminary draft agreements, correspondence of the negotiating states, records of their comments to the plenary committee, the reports of the committees, the reports of the speakers, and sometimes the public statements by theex oficio of the negotiating states, the state figures, and the materials recorded as "authentic interpretation", official letters, maps, ratified documents etc.

The interpretational practice of the ICJ shows the extension of the doctrinal approaches of the traditional perception of the travaux preparatoires as an auxiliary tool. The 
ICJ uses travaux preparatoires 1) to identify the intent of the legislator; 2) to provide advisory opinions; 3 ) to clarify the intentions of the parties to the treaty; 4) to determine the jurisdiction of the ICJ; 5) to identify the true intentions of the parties to the dispute; 6) to decide questions regarding the text, context, purpose and object of the treaty as a general rule of interpretation, fixed in Art. 31 of the Vienna Convention on the Law of Treaties, 1969.

\section{References}

1. Vienna Convention on the Law of Treaties, 23 May 1969. $\leq$ http://global.oup.com/booksites/content/9780198259466/15550012>

2. Convention on the Territorial Sea and the Contiguous Zone, Geneva, 29 April 1958. $<$ https://www.gc.noaa.gov/documents/8_1_1958_territorial_sea.pdf $>$

3. Fourth Geneva Conventions for the Protection of War Victims. 12 August 1949 $<$ https://www.refworld.org/docid/3ae6b36d2.html>

4. Convention for the Protection of Human Rights and Fundamental Freedoms $<$ https://www.echr.coe.int/Pages/home.aspx?p=basictexts\&c $>$

5. Report on the Work of the Conference of Governrnent Experts for the Study of the Conventions for the Protection of War Victims, Ceneva, 14-26 April 1947. P. 8.

6. Legal Consequences of the Construction of a Wall in the Occupied Palestinian Territory, Advisory Opinion, I.C.J. Reports 2004, p. 136. Para. 95. <https://www.icjcij.org/en/case/131.>

7. Maritime delimitation in the Black Sea (Romania v. Ukraine) (2008). Judgment, I.C.J. Reports 2009, p. 61.

8. Maritime Delimitation and Territorial Questions between Qatar and Bahrain, Jurisdiction and Admissibility, Judgment, I.C.J. Reports 1995, p. 6.

9. Maritime Delimitation in the Caribbean Sea and the Pacific Ocean (Costa Rica v. Nicaragua) and Land Boundary in the Northern Part of Isla Portillos (Costa Rica v. Nicaragua) International Court of Justice. General List Nos. 157 and 165. 2 February 2018.

10. Case concerning maritime delimitation and territorial questions between Qatar and Bahrain (Qatar v. Bahrain). Counter-memorial submitted by the state of Bahrain (questions of jurisdiction and admissibility). Volume I. 11 June 1992. Para 6-42.

11. Collected Edition of the "Travaux Préparatoires" of the European Convention on Human Rights $=$ Recueil des travaux preparatoires de la Convention europeenne des droits de l'homme / Council of Europe. The Hague ; Boston : M. Nijhoff; Hingham, MA : Kluwer Boston, [distributor], 1975-1985 $8 \mathrm{v}$.

12. Interpretation of Peace treaties with Bulgaria, Hungary and Romania. Advisory opinions of March 30th, July 18th, $1950<$ https://www.icj-cij.org/files/case-related/8/00819491104-REQ-1-00-EN.pdf.>

13. United Nations Conference on the Law of the Sea. Geneva, Switzerland 24 February to 27 April 1958 Document: A/CONF.13/18 Certain Legal Aspects Concerning the Delimitation of the Territorial Waters of Archipelagos Extract from the Official Records of the United Nations Conference on the Law of the Sea, Volume I (Preparatory Documents).

14. Bossuyt Marc J. (1987) Guide to the "Travaux Préparatoires" of the International Covenant on Civil and Political Rights. Dordrecht; Boston: M. Nijhoff.

15. Craven Matthew C. R. (1995) The International Covenant on Economic, Social, and Cultural Rights: A Perspective on its Development. Oxford: Clarendon Press.

16. Djeffal Christian (2016) Static and evolutive treaty interpretation : a functional reconstruction. Cambridge University Press.

17. Lars Rehof A. (1993) Guide to the Travaux Préparatoires of the United Nations Convention on the Elimination of all Forms of Discrimination Against Women. Dordrecht; Boston: M . Nijhoff. 
18. Mark van Khuk. (2012) Pravo kak kommunikatsiya / Per. s angl. M. V. Antonova i A. V. Polyakova. SPb. : Izdatelskiy dom S.-Peterb. gos. un-ta. OOO «Universitetskiy izdatelskiy konsortsium».

19. Sharon Detrick. (1992) The United Nations Convention on the Rights of the Child: A Guide to the "Travaux Préparatoires". Dordrecht; Boston: M. Nijhoff.

20. Weis Paul (1995) The Refugee Convention, 1951: The Travaux Préparatoires Analysed. Cambridge: Grotius Publications.

21. Wetzel Ralf Günter; Rauschning Dietrich (1978) The Vienna Convention on the Law of Treaties: Travaux Préparatoires. Frankfurt: Metzner

22. Zhignya K. L. (1981) Podgotovka i zaklyucheniye mirnykh dogovorov s Bolgariyey. Vengriyey i Rumyniyey posle vtoroy mirovoy voyny. Kishinev : Shtiintsa.

23. McDougal Myres S., "The International Law Commission's Draf Articles Upon Interpretation: Textuality Redivivus" (1967). Faculty Scholarship Series. Paper 2581. $<$ http://digitalcommons.law.yale.edu/fss_papers/2581>

24. Ris Martin (1991) Treaty Interpretation and ICJ Recourse to Travaux Préparatoires: Towards a Proposed Amendment of Articles 31 and 32 of the Vienna Convention on the Law of Treaties. Boston College International and Comparative Law Rewiev. Volume 14. Issue 1. Article 6

25. Detlev F. Vagts. Treaty Interpretation and the New American Ways of Law Reading Detlev F. Vagts, <http://ejil.org/pdfs/4/1/1214.pdf.>

26. Pratter Jonathan. À la Recherche des Travaux Préparatoires: An Approach to Researching the Drafting History of International Agreements, $<$ http://www.nyulawglobal.org/globalex/Travaux_Preparatoires.html.> 